46. Shinitzky M, Inbar M 1976 Microviscosity parameters and protein mobility in biological membranes. Biochim Biophys Acta 43:133

47. Singer SJ, Nicolson GL 1972 The fluid mosaic model of the structure of cell membranes. Science 175:720

48. Sinha M, Ganguli S, Sperling MA 1981 Disappearance of erythrocyte insulin receptors during maturation in sheep. Diabetes 30:411

49. Sinha J, Ganguli S, Suchy F, Sperling M 1982 Lack of functional linkage between insulin receptors and insulin action in fetal hepatocytes. In: 64th Annual Meeting, Endocrine Society, San Francisco, Abstracts, p 216, No 547 (see supplement to Endocrinology, vol 10)

50. Thorssen AV, Hintz RL 1977 Insulin receptors in the newborn: increase in receptor affinity and number. N Engl J Med 297:908

51. Vinocur P, Clark C Jr 1980 Characterization and significance of hepatic receptors for insulin in fetal and neonatal life. [Suppl 2] Diabetes 29:39A (abstr)
52. Yuli I, Tomonga A, Snyderman R 1982 Chemoattractant receptor functions in human polymorphonuclear leukocytes are divergently altered by membrane fluidizers. Proc Natl Acad Sci USA 79:5906

53. These studies were supported by grants from the National Foundation of the March of Dimes, The Donald E. Simon Foundation, The Juvenile Diabetes Foundation, The National Institutes of Health, National Institute of Arthritis, Diabetes, and Digestive Kidney Diseases Grant R01 AM 33503-01, and the American Diabetes Association of Southern California, as well as a gift from Tosco Corporation. Portions of this study were presented before the Meeting of the Society for Pediatric Research, February 1982 in Carmel, CA.

54. Address all correspondence to N. D. Neufeld, M.D., Section of Pediatric Endocrinology, Schuman Bldg. Room 516, Cedars-Sinai Medical Center, 8700 Beverly Boulevard, Los Angeles, California 90048.

55. Received for publication January 2, 1984.

\title{
Comparative Monovalent Cation Transport in Neonatal and Adult Red Blood Cells
}

\author{
AIXA MULLER-SOYANO, BONNIE W. RAMSEY, AND BERTIL E. GLADER ${ }^{13}$ \\ Institute of Hematology-Oncology, Caracas, Venezuela, Department of Pediatrics, University of Washington \\ School of Medicine, and Department of Pediatrics, Stanford University School of Medicine,
} Stanford, California, USA

\begin{abstract}
Summary
Active transport of $\mathrm{Na}$ and $\mathrm{K}$ under physiologic and maximally stressed conditions was identical in normal adult red blood cells (RBC) and term neonatal erythrocytes. These results are consistent with the previous observation that Na-K ATPase is the same in normal adult RBC and term neonatal erythrocytes. These data, however, are at variance with a previous observation that active $K$ transport is impaired in neonatal erythrocytes. The most reasonable explanation for this difference relates to inherent problems with the use of radioisotopes which were used in previous in vitro studies of cation transport.
\end{abstract}

\section{Abbreviations}

RBC, red blood cells

GBS, glycylglycine-buffered salt solution

It previously has been reported that active $\mathrm{K}$ transport is decreased in term neonatal RBC compared to normal adult erythrocytes (1). The explanation for this altered $\mathrm{K}$ transport was that neonatal RBC have decreased Na-K ATPase activity (8). Term neonatal $\mathrm{RBC}$ do in fact have decreased Na-K ATPase activity compared with adult reticulocyte-rich $\mathrm{RBC}$; however, there is no difference in enzyme activity when compared with normal adult $\mathrm{RBC}(8)$. The studies reported here were designed to resolve the paradox of why term neonatal $\mathrm{RBC}$ have decreased active $\mathrm{K}$ transport despite the fact that they contain the same $\mathrm{Na}-\mathrm{K}$ ATPase activity as that seen in normal adult RBC.

\section{MATERIALS AND METHODS}

General experimental design. Nonisotopic cation fluxes were measured in normal adult RBC and term neonatal erythrocytes. The ration flux studies were determined under normal phvsio- logic conditions and under conditions where the intracellular sodium concentration was elevated to maximally activate $\mathrm{Na}-\mathrm{K}$ ATPase (2).

Preparation of $R B C$. Blood was collected in EDTA from the umbilical cords of healthy term infants and from normal adult volunteers. Erythrocytes were separated from the plasma and buffy coat by centrifugation at $4^{\circ} \mathrm{C}$. The red blood cells next were washed three times in Na-GBS, pH $7.4\left(37^{\circ} \mathrm{C}\right)$ with the following composition: $145 \mathrm{mM} \mathrm{NaCl}, 5 \mathrm{mM} \mathrm{KCl}, 1 \mathrm{mM} \mathrm{Na}_{2} \mathrm{HPO}_{4}, 1$ $\mathrm{mM} \mathrm{MgCl} 2,5 \mathrm{mM}$ glucose, and $20 \mathrm{mM}$ glycylglycine.

Preparation of high sodium $R B C$. Na-loaded human RBC were prepared by incubating washed $\mathrm{RBC}(5 \%$ hematocrit in Na-GBS) with amphotericin B sulfate at a final concentration of $5 \mu \mathrm{g} / \mathrm{ml}$. After $2-\mathrm{h}$ incubation in a shaking water bath $(100$ oscillations/min) at $37^{\circ} \mathrm{C}, \mathrm{RBC}$ were washed five times with 20 volumes of Na-GBS containing bovine albumin $(1 \mathrm{~g} / \mathrm{dl})$. Albumin was added to bind and remove amphotericin from the cell suspension.

Measurement of $R B C$ cation transport. Red blood cells were suspended in Na-GBS (hematocrit 20\%) and incubated $4 \mathrm{~h}$ at $37^{\circ} \mathrm{C}$ in a shaking water bath (100 oscillations/min). Cell $\mathrm{Na}$ and medium $\mathrm{K}$ were measured every $30 \mathrm{~min}$ utilizing previously described methods $(3,4)$. Changes in cell $\mathrm{K}$ were determined indirectly from the hematocrit and medium $\mathrm{K}$ concentration. There was no hemolysis during these studies, and thus more precise measurements of net $\mathrm{K}$ efflux could be obtained by measuring medium $\mathrm{K}$ changes (increased values above a small number). Active transport was defined as the net cation difference between cells incubated in the presence and absence of ouabain $\left(10^{-4} \mathrm{M}\right)$.

\section{RESULTS}

Na-K active transport at low intracellular sodium concentrations. The fresh or "low" Na content of adult and neonatal RBC was maintained during the period of incubation. The mean cell 
Na concentration in adult $\mathrm{RBC}(9.9 \pm 0.9 \mathrm{meq} / \mathrm{liter} \mathrm{RBC})$ was similar to that in newborn erythrocytes $(10.1 \pm 1.1 \mathrm{meq} / \mathrm{liter}$ $\mathrm{RBC}$ ) (Table 1). In adult $\mathrm{RBC}$ with this low $\mathrm{Na}$ content, $\mathrm{Na}$ transport out of the cell $(1.3 \mathrm{meq} / \mathrm{liter} \mathrm{RBC} / \mathrm{h})$ was greater than active $\mathrm{K}$ transport inwards $(1.1 \pm 0.2 \mathrm{meq} / \mathrm{liter} \mathrm{RBC} / \mathrm{h})$, such that the $\mathrm{Na}: \mathrm{K}$ pump ratio was $1.2 \pm 0.1$. In newborn erythrocytes, active $\mathrm{Na}$ transport $(1.2 \pm 0.3 \mathrm{meq} / \mathrm{liter} \mathrm{RBC} / \mathrm{h})$ was similar to that seen in adult $R B C$ as was active $K$ transport $(1.0 \pm 0.2 \mathrm{meq} /$ liter $\mathrm{RBC} / \mathrm{h}$ ) and the $\mathrm{Na}: \mathrm{K}$ pump ratio $(1.2 \pm 0.2)$.

$\mathrm{Na}-\mathrm{K}$ active transport at high intracellular sodium concentrations. In RBC preloaded with $\mathrm{Na}$ in order to stimulate the $\mathrm{Na}-\mathrm{K}$ ATPase transport system, the mean cell Na during the incubation period was similar in adult $(41.9 \pm 3.2 \mathrm{meq} /$ liter $\mathrm{RBC})$ and neonatal $(45.2 \pm 5.8 \mathrm{meq} /$ liter $\mathrm{RBC})$ erythrocytes (Table 2). Moreover, there was no significant difference in active $\mathrm{Na}$ efflux (adult $=3.8 \pm 0.6 \mathrm{meq} /$ liter $\mathrm{RBC} / \mathrm{h}$, neonate $=3.6 \pm 0.7 \mathrm{meq} /$

Table 1. Active cation transport in adult and neonatal erythrocytes with a low Na content*

\begin{tabular}{|c|c|c|c|}
\hline & \multicolumn{3}{|c|}{$\mathrm{RBC}$ cation change (meq/liter $\mathrm{RBC} / \mathrm{h}$ ) } \\
\hline & Adult RBC & \multicolumn{2}{|c|}{ Neonatal RBC } \\
\hline & $\mathrm{Na}$ & $\mathrm{Na}$ & $\mathrm{K}$ \\
\hline $\begin{array}{l}\text { Without oua- } \\
\text { bain }\end{array}$ & $+(0.2 \pm 0.2)-(0.3 \pm 0.2)$ & $-(0.3 \pm 0.2)$ & $-(0.2 \pm 0.2)$ \\
\hline With ouabain & $+(1.5 \pm 0.3)-(1.4 \pm 0.3)$ & $+(0.9 \pm 0.3)$ & $-(1.2 \pm 0.2)$ \\
\hline Active transport & $1.3 \pm 0.2 \quad 1.1 \pm 0.2$ & $1.2 \pm 0.3$ & $1.0 \pm 0.2$ \\
\hline $\begin{array}{l}\text { Na:K pump ra- } \\
\text { tio }\end{array}$ & $1.2 \pm 0.2$ & \multicolumn{2}{|c|}{$1.2 \pm 0.2$} \\
\hline $\begin{array}{l}\text { Mean cell Na } \\
\text { (meq/liter } \\
\text { RBC) }\end{array}$ & $9.9 \pm 0.9$ & \multicolumn{2}{|c|}{$10.1 \pm 1.1$} \\
\hline
\end{tabular}

* Fresh adult and cord blood erythrocytes suspended in Na-GBS (hematocrit 20\%) were incubated in the presence and absence of ouabain $(0.1 \mathrm{mM})$. Changes in cell sodium (measured directly) and cell potassium (calculated from changes in medium $\mathrm{K}$ and hematocrit) were determined every 30 min over a 4-h period. Active action transport was calculated from the difference in net hourly cation change in the presence and absence of ouabain. The sodium/potassium pump ratio was calculated by dividing sodium-active transport by potassium-active transport. Mean cell $\mathrm{Na}$ is the average $\mathrm{RBC} \mathrm{Na}$ content during the period of incubation. Results are expressed as mean \pm 1 SD of seven separate experiments.

Table 2. Active cation transport in adult and neonatal erythrocytes with an elevated $\mathrm{Na}$ content*

\begin{tabular}{|c|c|c|}
\hline & \multicolumn{2}{|c|}{$\mathrm{RBC}$ cation change (meq/liter $\mathrm{RBC} / \mathrm{h}$ ) } \\
\hline & Adult RBC & Neonatal RBC \\
\hline & $\mathrm{Na}$ & $\mathrm{Na}$ \\
\hline $\begin{array}{l}\text { Without oua- } \\
\text { bain }\end{array}$ & $-(1.9 \pm 1.1)+(0.6 \pm 0.5)$ & $-(2.3 \pm 0.9)+(1.2 \pm 0.9)$ \\
\hline With ouabain & $+(1.9 \pm 1.2)-(2.4 \pm 0.8)$ & $+(1.3 \pm 0.6)-(1.6 \pm 0.6)$ \\
\hline Active transport & $3.8 \pm 0.6 \quad 3.0 \pm 0.5$ & $3.6 \pm 0.7 \quad 2.8 \pm 0.7$ \\
\hline $\begin{array}{l}\text { Na:K pump ra- } \\
\text { tio }\end{array}$ & $1.3 \pm 0.2$ & $1.3 \pm 0.4$ \\
\hline $\begin{array}{l}\text { Mean cell Na } \\
\text { (meq/liter } \\
\text { RBC) }\end{array}$ & $41.9 \pm 3.2$ & $45.2 \pm 5.8$ \\
\hline
\end{tabular}

* Sodium-loaded adult and cord blood erythrocytes suspended in NaGBS (hematocrit $20 \%$ ) were incubated in the presence and absence of ouabain $(0.1 \mathrm{mM})$. Changes in cell sodium (measured directly) and cell potassium (calculated from changes in medium $\mathrm{K}$ and hematocrit) were determined every $30 \mathrm{~min}$ over a 4-h period. Active cation transport was calculated from the difference in net hourly cation change in the presence and absence of ouabain. Sodium/potassium pump ratio was calculated by dividing sodium-active transport by potassium-active transport. Mean cell $\mathrm{Na}$ is the average RBC Na content during the period of incubation. Results are expressed as mean $\pm 1 \mathrm{SD}$ of eight sebarate experiments. liter $\mathrm{RBC} / \mathrm{h}$ ), active $\mathrm{K}$ influx (adult $=3.0 \pm 0.5 \mathrm{meq} /$ liter $\mathrm{RBC} /$ $\mathrm{h}$, neonate $2.8 \pm 0.7 \mathrm{meq} / \mathrm{liter} \mathrm{RBC} / \mathrm{h}$ ) or $\mathrm{Na}: \mathrm{K}$ pump ratio $($ adult $=1.3 \pm 0.2$, neonate $=1.3 \pm 0.4)$.

\section{DISCUSSION}

Despite the same Na-K ATPase activity in term infant and normal adult $\mathrm{RBC}$, it has been reported that active $\mathrm{K}$ transport is decreased in term neonatal $\mathrm{RBC}$ compared to normal adult erythrocytes (1). In these earlier studies, $\mathrm{K}$ transport was assessed utilizing ${ }^{42} \mathrm{~K}$, taking advantage of the fact that isotopic tracers allow precise determination of slow biochemical reactions which tax the sensitivity of chemical measurements. The utilization of tracer measurements, however, assumes that chemical behavior of the isotope is identical to the nonisotopic species. Unfortunately this assumption is not always correct. In the case of RBC monovalent cation transport, it has been demonstrated that measurements of ${ }^{42} \mathrm{~K}$ influx, as well as ${ }^{24} \mathrm{Na}$ outflux, do not necessarily correlate with active cation transport since isotopenonisotopic exchange reactions $\left({ }^{24} \mathrm{Na}-{ }^{23} \mathrm{Na}\right.$ exchange and ${ }^{42} \mathrm{~K}$ ${ }^{41} \mathrm{~K}$ exchange) also occur across the red cell membrane (6). These exchange reactions might be acceptable if they represented a constant fraction of observed isotope movement, but, unfortunately, isotopic exchange varies significantly in different RBC and with the metabolic state of erythrocytes $(6,7)$.

In order to circumvent the problems associated with the use of radioisotopes, we designed experiments that would allow direct chemical measurement of $\mathrm{Na}$ and $\mathrm{K}$. Active $\mathrm{Na}$ transport was measured by assessing changes in cell $\mathrm{Na}$ content over a period of time, while $\mathrm{K}$ transport was calculated on the basis of changes in medium $\mathrm{K}$ concentration during the same time interval. Moreover, these measurements were made under conditions where the transport rate was maximally stimulated following augmentation of the intracellular sodium concentration and stimulation of Na-K ATPase (2). The results of our study indicate that term neonatal $\mathrm{RBC}$ and normal adult $\mathrm{RBC}$ actively transport $\mathrm{K}$ at the same rate. Moreover, $\mathrm{Na}$ transport also is the same in term neonatal and normal adult RBC, and there is no difference in the Na:K pump ratio. These results are no surprise in view of the identical activity of Na-K ATPase in these cells, but they are different from a previous study which suggested that neonatal $\mathrm{RBC}$ have decreased active $\mathrm{K}$ transport (1). We have not determined the degree of isotopic exchange reactions in neonatal $\mathrm{RBC}$, but considering the many biochemical differences between neonatal and adult erythrocytes (5), it is most likely that significant exchange differences exist between neonatal and adult RBC. For this reason, we believe the most meaningful data regarding the functional significance of Na-K ATPase can be obtained by chemical measurement of monovalent cation changes under conditions where the enzyme and cation transport rate are maximally stimulated.

\section{REFERENCES AND NOTES}

1. Blum SF, Oski FA 1969 Red cell metabolism in the newborn infant. IV Transmembrane potassium flux. Pediatrics 43:396

2. Garrahan PJ, Glynn IM 1967 Factors affecting the relative magnitude of the sodium:potassium and sodium:sodium exchanges catalyzed by the sodium pump. J Physiol 192:189

3. Glader BE, Fortier N, Albala MM, Nathan DG 1974 Congenital hemolytic anemia associated with dehydrated erythrocytes and increased potassium loss. N Engl J Med 291:491

4. Glader BE, Nathan DG 1978 Cation permeability alterations during sickling: relationship to cation composition and cellular hydration of irreversibly sickled cells. Blood 51:983

5. Oski FA, Naiman JL 1982 Hematologic Problems of the Newborn. In Oski FA, Naiman JL (eds) WB Saunders Company, Philadelphia, pp 1-360

6. Sachs JR 1972 Recoupling the Na-K pump. J Clin Invest 51:3244

7. Segal GB, Feig SA, Glader BE, Muller A, Dutcher P, Nathan DG 1975 Energy metabolism in human erythrocytes: the role of phosphoglycerate kinase in cation transport. Blood 46:271

8. Whaun J, Oski FA 1969 Red cell stromal adenosine triphosphatase (ATPase) of newborn infants. Pediatr Res 3:105

9. All studies were approved by the Human Subjects Committee, The Children's Hospital Medical Center, Boston, MA.

10. Informed consent was nhtained from narticinants in thic ctudy 
11. This research was performed while Dr. Glader was a recipient of a Research Career Development Award AM-00435 from the National Institutes of Health. Support also was provided by NIH Grant AM-20879.

12. We wish to thank Margaret Macksey for technical assistance and Luella Walter for secretarial assistance in the preparation of this manuscript.
13. Address all correspondence to Dr. Bertil E. Glader, Division of Hematology/ Oncology, Children's Hospital at Stanford, 520 Willow Road, Palo Alto, CA 94304.

14. Received for publication December 14, 1983.

\title{
The Current Status of Auditory Brainstem Response Testing in Neonatal Populations
}

\author{
L. CLARKE COX ${ }^{(50)}$ \\ Department of Audiology, Cleveland State University, Cleveland, Ohio, USA
}

\begin{abstract}
Summary
The use of auditory brainstem response (ABR) for assessment of hearing in the neonate has not been without challenge. Although numerous articles have appeared, agreement regarding the utility of neonatal ABR testing does not exist. In review of the current studies and commentaries, a clear majority are favorable to neonatal ABR testing. These studies along with current test procedures are discussed.
\end{abstract}

\section{Abbreviations}

\begin{abstract}
ABR, auditory brainstem response NICU, neonatal intensive care unit COG- Crib-O-Gram
\end{abstract}

Since the initial reporting of ABR in 1970 by Jewett et al. (26), the potential of accurate evaluation of auditory function in the neonate has existed. With the subsequent reporting of use in the NICU in 1975 by Schulman-Galambos and Galambos (38), procedures for the assessment of that potential were initiated. Since 1975 , the research reported in the literature has grown exponentially each year. In spite of the large and increasing amount of research reported, severl issues have remained unresolved, viz., the applicability, reliability, and validity of neonatal ABR testing. In fact, because of these and other factors, some authors have begun to seriously question using ABR with neonates $(13,35,42)$.

. The need for early identification of infants with hearing loss is apparent. Normal language, learning, and social skill acquisition is contingent upon hearing. Although the incidence of hearing impairment in the general neonatal population is relatively low $(0.26 \%)(41)$, in NICU neonates the incidence is considerably higher $(2-10 \%)(16,39)$. Furthermore, the improved survival rate of neonates born weighing less than $1500 \mathrm{~g}(19,31)$ has increased the pool of infants in which a high incidence of hearing impairment is seen (16).

Because the need for early identification of hearing loss does exist and the current procedures that could identify hearing impairment in the neonate are open to question (ABR), a critical review of $A B R$ testing is in order. The purpose of this article is to summarize the current ABR literature, both pro and con, and to draw conclusions regarding its use based on the literature and the experience of the writer. The summary will not attempt to review early ABR literature primarily due to excellent reviews that are already published. The interested reader, however, would find Downs (13) very thorough.

The current literature pertinent to ABR testing of neonates and NICU populations is discussed and from several aspects (5$7,11,12,17,20,25,34,36,47)$. Weber (47) and Cox et al. (5, $6)$ have reported norms while Mjoen (32), Hecox et al. (20), Horning (24), and Cox et al. (7) have explored test reliability. The influence of various factors on the ABR have been explored by Barden and Peltzman (2), Bernard et al. (4), Galambos and Despland (15), Kileny et al. (27), Marshall et al. (29), Hecox and Cone (21), Hecox et al. (20), Cox et al. (8), and Roberts et al. (35). ABR as a screening tool has been reported by Horning (24), Crowell et al. (9), Hecox et al. (20), and Salamy et al. (37), while Simmons (43) and Galambos et al. (17) have compared ABR with Crib-O-Gram testing. These citations illustrate some of the current literature that is pertinent to neonatal ABR testing. In the following sections, specific aspects are discussed separately.

\section{TEST PROTOCOL}

The ABR protocol has undergone many refinements, a number of which have been facilitated by advances in commercial equipment. Factors considered in discussing current protocols include placement of the electrode, selection of intensity levels, test environment, state of the neonate, nature of the stimulus, and rate of presentation.

The most popular electrode configuration has usually been vertex $(\mathrm{Cz})$ active with ipsilateral mastoid or earlobe reference and contralateral mastoid or earlobe as ground $(2,4,9,12,20$, $27,34,36)$. With possible fontanel problems, however, several authors have found forehead placement of the active electrode instead of the vertex to be effective and simple $(7,18,25,28-$ $30,32,33,35)$.

Intensity levels are typically designated as normal hearing level (as before a jury of normal listeners), hearing level (corresponds to manufacturer's dial reading), sound pressure level $(0.0002$ dyne $/ \mathrm{cm}^{2}$ ), sensation level (amount of intensity above individual threshold), and peak equivalent (equivalent amplitude of pure tone on oscilliscopic display). For simplicity sake, normal hearing level is best to use with periodic rechecks either behaviorally or with sound pressure level measure once normal hearing level has been determined. 